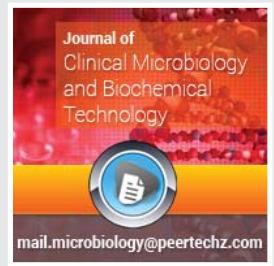

\title{
Microorganisms isolated from blood cultures in pediatrics clinic
}

\author{
Metin Dogan ${ }^{1 *}$, Muhammed Yusuf Ozan Avcı ${ }^{2}$, Abdullah \\ Akkus $^{2}$ and Mustafa Bulut ${ }^{3}$ \\ 'Department of Medical Microbiology, Meram Faculty of Medicine, Necmettin Erbakan University, \\ Konya, Turkey \\ ${ }^{2}$ Department of Pediatrics, Meram Faculty of Medicine, Necmettin Erbakan University, Konya, Turkey \\ ${ }^{3}$ Department of Pediatrics, Gümüşhane State Hospital, Gümüşhane, Turkey
}

Received: 28 December, 2019

Accepted: 28 January, 2020

Published: 29 January, 2020

*Corresponding author: Dr. Metin Dogan, Department of Medical Microbiology, Meram Faculty of Medicine, Necmettin Erbakan University, Selcuklu, Konya, Turkey, Tel: +90535 30716 15; +90332 23273 47; E-mail: metin_dogan42@yahoo.com

Keywords: Blood culture; Pediatric patients; Microorganisms

https://www.peertechz.com

\section{Check for updates}

\section{Abstract}

Because of high mortality and morbidity, identification of microorganisms causing sepsis is important for the treatment of the patient. Blood culture is the most valuable test for diagnosis and treatment. The aim of this study was to evaluate microorganisms isolated from blood cultures retrospectively.

Blood cultures accepted to the Medical Microbiology Laboratory between 01.01.2017 and 31.12.2017 was included in this study. Cultures were made with the incubation in automated system (BacT/Allert 3D, BioMerieux, France). Samples were then passaged to $5 \%$ sheep blood agar and Eosin Methylene Blue (EMB) medium and incubated at $37^{\circ} \mathrm{C}$ for $24-48$ hours. Cultured microorganisms were identified by conventional methods and MALDI-TOF MS/VITEC 2 system (BioMerieux, France).

Blood culture results of 1004 patients were analyzed retrospectively. 568(56.6\%) were identified as Coagulase Negative Staphylococci (CNS), $125(12.5 \%)$ were K.pneumoniae, 50(5.0\%) were S. aureus, 50(5.0\%) Candida spp., 30(3\%) were identified as Acinetobacter spp., followed by other microorganisms.

In this study, most common isolated microorganisms were CNS in blood cultures. Considering that most of these microorganisms were isolated in single blood culture, most of them were thought to be contaminant. Therefore, at least two sets of blood cultures should obtained to be beneficial to accurate diagnosis. In addition, It should be kept in mind may be cause to sepsis of $K$. pneumoniae, $S$. aureus, Candida spp., and other microorganisms.

\section{Introduction}

Nowadays, hospitalization rates of patients are increasing in parallel with the improvements in care and treatment. Long-term hospitalizations for the treatment of chronic diseases, especially cancer, etc., increase the risk of infection in all patients, especially in immune-compromised patients and patients with poor general status. Nosocomial infections are more common due to the administration of broadspectrum antibiotics to patients, life support through invasive procedures, and longer hospital stay $[1,2]$.

Blood and circulatory system infections are the most important infections affecting morbidity and mortality. Increased invasive procedures to diagnosis and treatment, increased cancer surgery and organ transplantation, and widespread use of immunosuppressive therapies are some of the risk factors for blood and circulatory system infections [3]. Blood culture is an important diagnostic method used to isolate microorganisms that cause bacteremia and is an important in terms of guiding the treatment $[4,5]$.

Nosocomial infections agents, especially sepsis agents, vary from country to country, from hospital to hospital, depending on the country's development status, antibiotic use strategies, and general condition and characteristics of patients. Even in different hospital units, different microorganisms can cause infections. Determining the diversity of microorganisms growing in blood cultures and determining antibiotic susceptibilities are important to precautions effective infection 
control measures, to establish empirical treatment protocols and initiate appropriate treatment [6].

Because of high mortality and morbidity, identification of microorganisms causing sepsis is important for the treatment of the patient. Blood culture is the most valuable test for diagnosis and treatment. The aim of this study was to evaluate microorganisms isolated from blood cultures retrospectively.

\section{Materials and methods}

Blood cultures accepted to the Medical Microbiology Laboratory that obtained from patients hospitalized in the pediatric clinic of Necmettin Erbakan University Meram Medical Faculty Hospital between 01.01.2016 and 31.12.2017 was included in this study. Blood culture results of 1004 patients were analyzed retrospectively.

After the children's skin was cleaned with baticon/alcohol, blood was taken with a sterile syringe. The optimal amount of blood in children was considered to be $1-5 \mathrm{ml}$. With a practical approach, $1 \mathrm{ml}$ of blood was taken for every age from children of 1 to 6 years old, and $5 \mathrm{ml}$ from older 6 years old.

Cultures were made with the incubation in automated system (BacT/Allert 3D, BioMerieux, France). Gram staining was made from the vials that gave positive signals during the incubation period and the result was given as preliminary information to the relevant clinic. Samples were then passaged to $5 \%$ sheep blood agar and eosin methylene blue (EMB) medium and incubated at $37^{\circ} \mathrm{C}$ for $24-48$ hours. Cultured microorganisms were identified by conventional methods and MALDI-TOF MS/VITEC 2 system (BioMerieux, France).

\section{Results}

Of the 1004 microorganisms isolated from blood cultures, $568(56.6 \%)$ were identified as coagulase negative staphylococci (CNS), 125 (12.5\%) were K.pneumoniae, 50(5.0\%) were S. aureus, 50(5.0\%) Candida spp., 30(3\%) were identified as Acinetobacter spp., followed by other microorganisms. The microorganisms isolated according to years shows in Table 1.

Table 1: The microorganisms isolated according to years.

\begin{tabular}{|c|c|c|c|c|}
\hline Isolated microorganisms & $\begin{array}{c}\mathbf{2 0 1 6} \text { year } \\
\mathbf{n - \%}\end{array}$ & $\begin{array}{c}\mathbf{2 0 1 7} \text { year } \\
\mathbf{n - \%}\end{array}$ & $\begin{array}{c}\mathbf{2 0 1 8} \text { year } \\
\mathbf{n - \%}\end{array}$ & $\begin{array}{c}\text { Total } \\
\mathbf{n}-\%\end{array}$ \\
\hline CNS* & $120-49.8 \%$ & $262-58.4 \%$ & $186-59.2 \%$ & $50-56.6 \%$ \\
\hline K.pneumoniae & $43-17.9 \%$ & $49-10.9 \%$ & $33-10.5 \%$ & $125-12.5 \%$ \\
\hline S. aureus & $9-21.7 \%$ & $33-7 . \%$ & $8-2.5 \%$ & $50-5 \%$ \\
\hline Candida spp. & $24-10 \%$ & $17-3.8 \%$ & $9-2.9 \%$ & $50-5 \%$ \\
\hline Acinetobacter spp. & $3-1.3 \%$ & $15-3.4 \%$ & $12-3.8 \%$ & $30-3 \%$ \\
\hline E. coli & $8-3.3 \%$ & $12-2.7 \%$ & $8-2.5 \%$ & $28-2.8 \%$ \\
\hline Enterococcus spp. & $8-3.3 \%$ & $10-2.2 \%$ & $9-2.9 \%$ & $27-2.7 \%$ \\
\hline P. aeruginosa & $7-2.9 \%$ & $11-2.5 \%$ & $7-2.2 \%$ & $25-2.5 \%$ \\
\hline E. cloacae & $6-2.5 \%$ & $6-1.3 \%$ & $4-1.3 \%$ & $16-1.6 \%$ \\
\hline Others & $13-5.4 \%$ & $34-7.6 \%$ & $38-12.1 \%$ & $85-2.5 \%$ \\
\hline Total & 241 & 449 & 314 & 1004 \\
\hline
\end{tabular}

* Coagulase negative staphylococci.

\section{Discussion}

Bloodstream infections are the most frequent infections in pediatric patients and one of the most serious and potentially life-threatening infectious diseases. Early diagnosis and therapy are essential for the prevention of morbidity and mortality [7].

In the majority of cases, antimicrobial therapy must be admitted empirically in these patients generally. The accuracy in predicting the pathogen and antimicrobial resistance patterns is crucial for successful therapy [8]. For this reason, it is necessary to know the microorganisms that grow in the hospital. Growing microorganisms vary according to hospitals.

In a study, which researched nosocomial bloodstream infections of pediatric patients in Brazilian, it is reported that the most common isolated pathogens were coagulasenegative staphylococci (CoNS) (21.3\%), Klebsiella spp. (15.7\%), Staphylococcus aureus (10.6\%), and Acinetobacter spp. (9.2\%) [9]. It is reported that $S$. aureus to be the most common cause of nosocomial bloodstream infections, followed by Klebsiella pneumoniae and coagulase-negative staphylococci, respectively in a study [10].

In Gaziantep Children's Hospital, CNS was most frequently isolated in blood cultures, followed by Salmonella spp, S. aureus, Klebsiella and streptococci species, respectively [11]. In another study, E.coli, Klebsiella and CNS were the most frequently isolated microorganisms [12]. It is reported by Birol, et al., [13], that the most common isolates included $1000(35.6 \%)$ coagulase-negative staphylococci, $782(27.8 \%)$ S. aureus and 303(10.8\%) Escherichia coli [13].

Tao, et al., [14], reported that A. baumannii was the most common microorganism identified, followed by $P$. aeruginosa $(17.2 \%)$, K. pneumoniae $(11.9 \%)$, and S. aureus (11.9\%) in patients with device-associated healthcare-associated infections, S. aureus was the most common organism in patients with central line-associated bloodstream infection. Ben Jaballah, et al., [15], reported that $S$. aureus to be the most common cause of nosocomial bloodstream infections, followed by Klebsiella pneumoniae and CNS, respectively in a study from a Tunisia.

As seen in the studies, isolated microorganisms vary according to regions. CNS was reported as highest isolated microorganism some studies $[9,11,13]$. In this study, the most frequently isolated microorganisms were CNS, but isolation ratio was very high. It can be associated with contamination. Other isolated microorganisms were K. pneumoniae, S. aureus, Candida spp., Acinetobacter spp., respectively, similar to other studies.

Blood culture is one of the most important tests used in the diagnosis of sepsis. In our laboratory, most commonly, CNS was isolated in blood cultures. Considering that most of these microorganisms were isolated in single blood culture, most of them were thought to be contaminant. Therefore, at least two sets of blood cultures should obtained to be beneficial to accurate diagnosis. In addition, It should be kept in mind may 
be cause to sepsis of K. pneumoniae, S. aureus, Candida spp., and other microorganisms.

\section{References}

1. Öncül A, Koçulu S, Elevli K (2012) Bir devlet hastanesinin yoğun bakım ünitelerinde kazanılan hastane enfeksiyonlarının epidemiyolojisi. Şişli Etfa Hastanesi Tıp Bülteni 46: 60-66. Link: http://bit.ly/2Ry450l

2. Orucu M, Geyik MF (2008) Yoğun bakım ünitesinde sık görülen enfeksiyonlar Düzce Tıp Fakültesi Derg 1: 40-43. Link: http://bit.ly/2t56upR

3. Sevim S, Öztürk Ş, Coşkuner A, Özgenç O, Avci M (2007) Bactec kan kültür sistemi ile izole edilen mikroorganizmaların değerlendirilmesi. İnfeksiyon Dergisi 21: 135-140. Link: http://bit.ly/2tPmhd1

4. Yüce $P$, Demirdağ $K$, Kalkan A (2005) Kan Kültürlerinde izole edilen mikroorganizmalar ve antibiyotik duyarlılıkları. Ankem Derg 19: 17-21.

5. Gülfem E (2013) Kan kültüründe üreyen izolatların dağılım ve antibiyotik duyarlılık profilinin Incelenmesi. The Medical Bulletin of Haseki 51: 151-156. Link: http://bit.ly/2Gvel3b

6. Mehli M, Gayyurhan ED, Zer Y, Akgün S, Akın EÖ, et al. (2007) Gaziantep Üniversitesi Tıp Fakültesi hastanesinde kan kültürlerinden izole edilen mikroorganizmalar ve antibiyotik duyarlılıkları. Infeksiyon Derg 21: 141-145. Link: http://bit.ly/2vyfgoJ

7. Gray J, Gossain S, Morris K (2001) Three-year survey of bacteremia and fungemia in a pediatric intensive care unit. Pediatr Infect Dis J 4: 416-421. Link: http://bit.ly/36G2ied

8. Berner R, Sauter S, Duffner U, Brandis M, Niemeyer CM (1998) Bacteremic episodes in pediatric oncologic patients, especially caused by the Streptococcus viridans group. Klin Padiatr 210: 256-260. Link: http://bit.ly/2U6HtGa

9. Pereira CAP, Marra AR, Camargo LFA, Pignatari ACC, Sukiennik T, et al. (2013) Nosocomial Bloodstream Infections in Brazilian Pediatric Patients: Microbiology, Epidemiology, and Clinical Features. PLoS One 8: e68144. Link: http://bit.ly/2RCc3W8

10. Jaballah NB, Bouziri A, Mnif K, Hamdi A, Khaldi A, et al. (2007) Epidemiology of hospital-acquired bloodstream infections in a Tunisian pediatric intensive care unit: a 2-year prospective study. Am J Infect Control 35: 613-618. Link: http://bit.ly/37CYPOB

11. Yiş R (2015) Güneydoğu Anadolu Bölgesi'nde bir çocuk hastanesinde kan kültürü sonuçlarının değerlendirilmesi. Türk Ped Arş 50: 102-107. Link: http://bit.ly/2tPRInz

12. Yılmaz S, Gümral R, Güney M, Bedir O, Güçlü AÜ, et al. (2013) íki ylllık dönemde kan kültürlerinden izole edilen mikroorganizmalar ve antibiyotik duyarlııkların değerlendirilmesi. Gülhane Tıp Derg 55: 247-252. Link: http://bit.ly/2RATxhe

13. Şafak B, Kılınç O (2016) Microorganisms Isolated From Blood Cultures during 2010-2015 and Their Antimicrobial Susceptibilities. Klimik Dergisi 29: 60-64. Link: http://bit.ly/37CFFZ8

14. Tao L, Hu B, Rosenthal VD, Gao X, He L (2011) Device-associated infection rates in 398 intensive care units in Shanghai, China: International Nosocomia Infection Control Consortium (INICC) findings. Int J Infect Dis 15: e774-e780. Link: http://bit.ly/37HyMWM

15. Ben Jaballah N, Bouziri A, Mnif K, Hamdi A, Khaldi A, et al. (2007) Epidemiology of hospital-acquired bloodstream infections in a Tunisian pediatric intensive care unit: a 2-year prospective study. Am J Infect Control 35: 613-618. Link: http://bit.ly/2Gtc74t
Discover a bigger Impact and Visibility of your article publication with

\section{Peertechz Publications}

Highlights

* Signatory publisher of ORCID

- Signatory Publisher of DORA (San Francisco Declaration on Research Assessment)

* Articles archived in worlds' renowned service providers such as Portico, CNKI, AGRIS, TDNet, Base (Bielefeld University Library), CrossRef, Scilit, J-Gate etc.

* Journals indexed in ICMJE, SHERPA/ROMEO, Google Scholar etc.

* OAI-PMH (Open Archives Initiative Protocol for Metadata Harvesting)

* Dedicated Editorial Board for every journal

* Accurate and rapid peer-review process

Increased citations of published articles through promotions

* Reduced timeline for article publication

Submit your articles and experience a new surge in publication services (https://www.peertechz.com/submission).

Peertechz journals wishes everlasting success in your every endeavours.

Copyright: @ 2020 Dogan M, et al. This is an open-access article distributed under the terms of the Creative Commons Attribution License, which permits unrestricted use, distribution, and reproduction in any medium, provided the original author and source are credited. 